\title{
Effects of selected agronomical factors on the content of health-promoting compounds in spaghetti squash (Cucurbita pepo L. subsp. pepo)
}

\author{
Wanda Wadas $^{1 *}$, Halina Mioduszewska ${ }^{2}$, Krzysztof Kalinowski ${ }^{1}$ \\ ${ }^{1}$ Department of Vegetable Crops \\ ${ }^{2}$ Department of Plant Physiology and Genetics \\ Siedlce University of Natural Sciences and Humanities \\ B. Prusa 14, 08-110 Siedlce, Poland
}

\begin{abstract}
The study examined the effects of the sowing date (5, 15 and 25 May $)$ and plant spacing $(1 \times 0.6 \mathrm{~m}, 1 \times 0.8 \mathrm{~m}$ and $1 \times 1 \mathrm{~m}$ ) on the content of carotenoids and L-ascorbic acid in the fruits of two cultivars of spaghetti squash ('Makaronowa Warszawska' and 'Pyza'). The field experiment was carried out in central-eastern Poland. Fully mature spaghetti squash fruits were harvested from the beginning of September to the beginning of October. The content of total carotenoids and $\beta$-carotene was the greatest in the fruits of plants sown on 15 May. The sowing date did not affect the content of L-ascorbic acid. Increasing the plant spacing from $1 \times 0.6 \mathrm{~m}$ to $1 \times 1 \mathrm{~m}$ resulted in an increase of total carotenoid content, particularly for the spaghetti squash sown on 25 May. Plant spacing did not have a significant effect on the content of $\beta$-carotene and L-ascorbic acid. Fruits of the 'Makaronowa Warszawska' with light orange flesh contained more total carotenoids and $\beta$-carotene than fruits of the 'Pyza' with cream-coloured flesh. The content of L-ascorbic acid in the fruits of both cultivars did not differ significantly.
\end{abstract}

Key words: $\beta$-carotene, carotenoids, L-ascorbic acid, plant spacing, sowing date

\section{INTRODUCTION}

Vegetables play an important role in human nutrition. A diet rich in vegetables provides many biologically active compounds, which fulfil an important role in preserving health and in the prevention of various diseases (Janeczko 2003, Lipecki and Libik 2003, Cieślik 2009). Vegetables are a main source of ascorbic acid and carotenoids. As strong antioxidants and free radical scavengers, ascorbic acid and carotenoids are particularly important for human health, preventing many cancers and cardiovascular diseases. Their health- promoting importance results not only from their antioxidant properties, but also from their participation in numerous metabolic processes that strengthen the immunological system of the body (Naidu 2003, Kopsell and Kopsell 2006). Cucurbits, including pumpkin and squash, are a rich source of carotenoids, particularly $\beta$-carotene, and ascorbic acid (Murkowic et al. 2002, Janeczko 2003, Cieślik 2009, Perkins-Veazie 2010). In general, pumpkin contains more carotene and ascorbic acid than squash (Danilchenko 2002, Murkovic et al. 2002, Biesiada et al. 2006). Pumpkin is a vegetable that is not as popular in Poland as zucchini and summer 
squash. The accumulation of carotenoids and ascorbic acid in vegetables depends not only on the species, but also on many pre- and post-harvest factors. Amongst the pre-harvest factors, light intensity and temperature are the most important in determining the final ascorbic acid and carotenoid content in vegetables (Lee and Kader 2000, Kopsell and Kopsell 2006, Lester 2006). The aim of the study was to determine the effect of the sowing date and plant spacing on the content of carotenoids and L-ascorbic acid in the fruits of spaghetti squash. Although spaghetti squash is still little known in Poland, it may contend with zucchini and summer squash. Its long fruits have flesh made of fibres arranged crosswise to the axis of the fruit, which, after cooking, form spaghetti-like threads. Some researchers have discussed the effects of agronomic factors on the chemical composition of various species of squash, but there are few studies concerning spaghetti squash (Paris 1993, Danilchenko 2002, Wojdyła et al. 2007).

\section{MATERIAL AND METHODS}

The study was carried out in 2007-2009 in the central-eastern part of Poland. The effect of the sowing date $(5,15$ and 25 May) and plant spacing $(1 \times 0.6 \mathrm{~m}, 1 \times 0.8 \mathrm{~m}$ and $1 \times 1 \mathrm{~m}$, i.e. 16,668 , 12,500 and 10,000 plants per hectare) on the content of health-promoting compounds in spaghetti squash ('Makaronowa Warszawska' and 'Pyza') was investigated. The 'Makaronowa Warszawska' features a bush plant habit with medium-sized, oblong, green spotted fruit with a light orange flesh. The 'Pyza' features a bush plant habit with medium-sized, elliptical, orange fruit with creamcoloured flesh.

The field experiment was established in a splitblock-split-plot design in three replications, on a loamy soil characterised by a low to average available potassium content, average to high phosphorus and magnesium content, and $\mathrm{pH}$ in $\mathrm{H}_{2} \mathrm{O}$ of 6.1-6.7. The area of each plot was $20 \mathrm{~m}^{2}$. Manure in a dose of $30 \mathrm{t} \mathrm{ha}^{-1}$ was applied in the autumn, and mineral fertilisers in doses of $120 \mathrm{~kg} \mathrm{~N}$ (ammonium nitrate), $52 \mathrm{~kg}$ P (Superphosphate) and $200 \mathrm{~kg} \mathrm{~K}$ (potassium sulphate) per hectare were applied in spring. $2 / 3$ of the nitrogen and potassium dose was applied before sowing and $1 / 3$ while the first fruits were setting. During plant vegetation, weeding and soil loosening were carried out, particularly in the initial period of plant growth, until the leaves covered the soil. Fruits were harvested during full maturity, from the beginning of September to the beginning of October. The total fruit yield and marketable yield per hectare were determined, as well as the number of marketable fruits per plant and the average weight of the marketable fruit. The results were discussed by Wadas and Kalinowski (2010). For laboratory studies, ten fruits of each treatment were taken. The edible parts of the fresh fruits comprised the research material. Fruits were peeled with a stainless steel knife and seeds were separated. The content of total carotenoids and $\beta$-carotene, and the content of L-ascorbic acid were determined. The total carotenoid and $\beta$-carotene content were spectrophotometrically determined according to the Polish standard (PN90/A-75101.12), and the L-ascorbic acid content was determined using the Tillmans titrimetric method (PN-90/A-75101.11). The results of the experiment were analysed statistically by analysis of variance. The significance of differences was verified using the Tukey test at $\mathrm{p}=0.05$.

Thermal and humidity conditions favourable for the growth and development of spaghetti squash plants occurred only in 2007 (Tab. 1). In 2008 and 2009, low air temperature and intensive precipitation in May resulted in poor emergence and a very cool period that began in the middle of September 2008, with a nearly $10^{\circ} \mathrm{C}$ drop in average temperature and intensive precipitation, delaying fruit ripening.

\section{RESULTS AND DISCUSSION}

Meteorological conditions during the spaghetti squash vegetation period had a significant effect on the content of carotenoids and L-ascorbic

Table 1. Mean air temperature and precipitation sums in the vegetation period of spaghetti squash

\begin{tabular}{|c|c|c|c|c|c|c|c|c|}
\hline \multirow[b]{2}{*}{ Months } & \multicolumn{4}{|c|}{ Temperature $\left({ }^{\circ} \mathrm{C}\right)$} & \multicolumn{4}{|c|}{ Rainfall (mm) } \\
\hline & 2007 & 2008 & 2009 & $\begin{array}{c}\text { mean } \\
1981-2005\end{array}$ & 2007 & 2008 & 2009 & $\begin{array}{c}\text { mean } \\
1981-2005\end{array}$ \\
\hline May & 14.6 & 12.7 & 12.9 & 11.9 & 59.1 & 85.6 & 68.9 & 49.7 \\
\hline June & 18.2 & 17.4 & 15.7 & 16.7 & 59.0 & 49.0 & 145.2 & 63.0 \\
\hline July & 18.9 & 18.4 & 19.4 & 19.5 & 70.2 & 69.8 & 26.4 & 60.3 \\
\hline August & 18.9 & 18.5 & 17.7 & 18.4 & 31.1 & 75.4 & 80.9 & 59.8 \\
\hline September & 13.1 & 12.2 & 14.6 & 13.1 & 67.6 & 63.3 & 24.9 & 53.0 \\
\hline
\end{tabular}


acid in the fruits (Tabs 2-4). The highest content of carotenoids and, at the same time, the lowest content of L-ascorbic acid were recorded in 2009, with the highest average air temperature and the lowest amount of precipitation in September, in the fruit ripening period. In that year, the content of total carotenoids and of $\beta$-carotene was on average over three times higher, while L-ascorbic acid content was lower by about $12 \mathrm{mg} \mathrm{kg}^{-1}$ f.m. (19\%) than in the other years of the study. Rainy, cloudy and cool conditions decrease ascorbic acid and carotene levels in most vegetables (Lee and Kader 2000, Kopsell and Kopsell 2006, Lester 2006), which was confirmed by the present study. Rainfall effects are primarily due to a combination of light and temperature.

The sowing date of spaghetti squash had a significant effect on the content of carotenoid compounds in fruits. The highest content of total carotenoids and $\beta$-carotene was found in plants sown on 15 May (Tabs 2 and 3). The total carotenoid content for plants sown on 15 May was higher, on average, by $17.30 \mathrm{mg} \mathrm{kg}{ }^{-1}$ f.m. (18.4\%) in comparison to plants sown on 5 May, and by
$18.83 \mathrm{mg} \mathrm{kg}^{-1}$ f.m. (20.4\%) in comparison to those sown on 25 May. The difference in $\beta$-carotene content was $6.30 \mathrm{mg} \mathrm{kg}^{-1}$ f.m. (44.7\%) and 2.19 $\mathrm{mg} \mathrm{kg}{ }^{-1}$ f.m. (12.0\%), respectively. The sowing date of spaghetti squash had the greatest effect on carotenoid accumulation in fruits in 2008, with the lowest air temperature and quite heavy rainfall in the second half of August and in September, during the fruit ripening period. In that year, for plants sown on 5 and 15 May, the total carotenoid content in fruits was higher on average by $17.66 \mathrm{mg} \mathrm{kg}^{-1}$ f.m. $(43.0 \%)$ in comparison to the plants sown on 25 May, but the content of $\beta$-carotene did not differ significantly. In other years of the research, with higher air temperatures in September, the content of $\beta$-carotene in spaghetti squash fruits was higher for the later sowing date. A study carried out by other researchers shows the significant effect of the sowing date on the total carotenoid and $\beta$-carotene content in melon fruits (Wolbang et al. 2010). The carotenoid content depends on the amount of active radiation absorbed photosynthetically by plants and the temperature during the intensive growth of vegetables (Krzesiński and Knaflewski

Table 2. Total carotenoid content in spaghetti squash fruits depending on sowing date and plant spacing (mg $\mathrm{kg}^{-1} \mathrm{f} . \mathrm{m}$.)

\begin{tabular}{|c|c|c|c|c|c|c|c|c|c|c|c|c|}
\hline \multirow{3}{*}{$\begin{array}{l}\text { Sowing } \\
\text { date }\end{array}$} & \multicolumn{11}{|c|}{ Cultivar and plant spacing (m) } & \multirow{3}{*}{ Mean } \\
\hline & \multicolumn{4}{|c|}{ Makaronowa Warszawska } & \multicolumn{4}{|c|}{ Pyza } & \multicolumn{3}{|c|}{ mean } & \\
\hline & $1 \times 0.6$ & $1 \times 0.8$ & $1 \times 1$ & mean & $1 \times 0.6$ & $1 \times 0.8$ & $1 \times 1$ & mean & 10.6 & $1 \times 0.8$ & $1 \times 1$ & \\
\hline \multicolumn{13}{|c|}{2007} \\
\hline 5 May & 63.75 & 62.64 & 58.38 & 61.59 & 47.18 & 44.22 & 43.70 & 45.04 & 55.46 & 53.40 & 51.00 & 53.30 \\
\hline 15 May & 58.96 & 52.58 & 88.12 & 66.65 & 41.34 & 43.30 & 58.20 & 47.61 & 50.15 & 47.90 & 73.30 & 57.10 \\
\hline 25 May & 44.62 & 54.40 & 90.64 & 63.22 & 39.09 & 57.72 & 53.44 & 50.08 & 41.85 & 56.06 & 72.04 & 56.65 \\
\hline Mean & 55.78 & 56.54 & 79.05 & 63.82 & 42.54 & 48.41 & 51.78 & 47.58 & 49.16 & 52.48 & 65.46 & 55.70 \\
\hline \multicolumn{13}{|c|}{2008} \\
\hline 5 May & 61.69 & 73.01 & 73.30 & 69.33 & 28.30 & 71.60 & 51.64 & 50.51 & 45.00 & 72.30 & 62.50 & 59.90 \\
\hline 15 May & 76.03 & 78.82 & 71.74 & 75.53 & 30.37 & 40.04 & 46.69 & 39.03 & 53.20 & 59.40 & 59.20 & 57.30 \\
\hline 25 May & 40.68 & 37.21 & 66.79 & 48.23 & 27.64 & 32.12 & 41.46 & 33.74 & 34.16 & 34.66 & 54.12 & 40.98 \\
\hline Mean & 59.47 & 63.01 & 70.61 & 64.36 & 28.77 & 47.92 & 46.60 & 41.09 & 44.12 & 55.46 & 58.60 & 52.73 \\
\hline \multicolumn{13}{|c|}{2009} \\
\hline 5 May & 149.50 & 175.97 & 182.47 & 169.31 & 136.90 & 186.23 & 177.10 & 166.74 & 143.20 & 181.10 & 179.80 & 168.00 \\
\hline 15 May & 238.60 & 278.60 & 257.43 & 258.21 & 156.17 & 194.43 & 188.50 & 179.70 & 197.38 & 236.50 & 223.00 & 219.00 \\
\hline 25 May & 184.60 & 174.77 & 231.90 & 197.09 & 130.37 & 164.37 & 189.10 & 161.28 & 157.48 & 169.57 & 210.50 & 179.18 \\
\hline Mean & 190.90 & 209.78 & 223.93 & 208.20 & 141.15 & 181.68 & 184.90 & 169.24 & 166.02 & 195.73 & 204.42 & 188.72 \\
\hline \multicolumn{13}{|c|}{ mean } \\
\hline 5 May & 91.65 & 103.87 & 104.71 & 100.08 & 70.79 & 100.68 & 90.82 & 87.43 & 81.22 & 102.30 & 97.80 & 93.80 \\
\hline 15 May & 124.53 & 136.67 & 139.20 & 133.46 & 75.96 & 92.59 & 97.80 & 88.78 & 100.24 & 114.60 & 118.50 & 111.10 \\
\hline 25 May & 89.97 & 88.79 & 129.78 & 102.84 & 65.70 & 84.73 & 94.66 & 81.70 & 77.83 & 86.76 & 112.22 & 92.27 \\
\hline Mean & 102.05 & 109.79 & 124.56 & 112.13 & 70.82 & 92.67 & 94.43 & 85.97 & 86.43 & 101.22 & 109.49 & 99.05 \\
\hline
\end{tabular}


2002, Lester 2006). The sowing date, as well as weather conditions, changed the amount of solar radiation that was absorbed. In consequence, it affected carotenoid production. The study did not show any significant effects of the spaghetti squash sowing date on the content of L-ascorbic acid in fruits (Tab. 4). In a study conducted by other authors, the sowing date had a significant effect on the L-ascorbic acid content in sweet pepper fruits. The fruits from plants transplanted into the field in the end of first 10 days of June contained the most L-ascorbic acid, as compared to earlier transplantation dates (Buczkowska and Sawicki 2008).

Plant spacing had a significant effect on the content of carotenoid compounds in spaghetti squash fruits (Tab. 2). The highest total carotenoid content was found in the fruits of plants sown with $1 \times 1 \mathrm{~m}$ spacing. The decrease in the distance between plants in a row resulted in a decrease of the carotenoid content in fruits. The content of total carotenoids in the fruits of plants sown with $1 \times 1 \mathrm{~m}$ spacing $(10,000$ plants per hectare) was higher, on average, by $23.06 \mathrm{mg} \mathrm{kg}^{-1}$ f.m. (26.6\%), and by $14.79 \mathrm{mg} \mathrm{kg}^{-1}$ f.m. (17.1\%) for $1 \times 0.8 \mathrm{~m}$ spacing $(12,500$ plants per hectare), in comparison to $1 \times 0.6 \mathrm{~m}$ spacing $(16,668$ plants per hectare) . Differences in $\beta$-carotene content were lower and were not statistically confirmed (Tab. 3). Plant spacing had the greatest effect on the accumulation of carotenoids in spaghetti squash fruits in 2008, with the highest number of cloudy days and quite heavy rainfall in the second half of August and in September, in the period of fruit ripening. In that year, the content of total carotenoids in fruits for $1 \times 1 \mathrm{~m}$ plant spacing was higher, on average, by $14.48 \mathrm{mg} \mathrm{kg}^{-1}$ f.m. (32.8\%), and by $11.34 \mathrm{mg}$ $\mathrm{kg}^{-1}$ f.m. $(25.7 \%)$ for $1 \times 0.8 \mathrm{~m}$ plant spacing in comparison to the $1 \times 0.6 \mathrm{~m}$ plant spacing. Plant spacing had a greater effect on the content of total carotenoids for plants sown on 25 May than for plants sown on 5 and 15 May. For the sowing date of 25 May, the increase in the distance between plants in a row from 0.6 to $1 \mathrm{~m}$ resulted in an increase of total carotenoid content in fruits by $34.39 \mathrm{mg} \mathrm{kg}^{-1}$ f.m. (44.2\%) on average. In 2007 and 2008, the differences were higher than in 2009, the year with

Table 3. $\beta$-carotene content in spaghetti squash fruits depending on sowing date and plant spacing (mg kg-1 f.m.)

\begin{tabular}{|c|c|c|c|c|c|c|c|c|c|c|c|c|}
\hline \multirow{3}{*}{$\begin{array}{l}\text { Sowing } \\
\text { date }\end{array}$} & \multicolumn{11}{|c|}{ Cultivar and plant spacing $(\mathrm{m})$} & \multirow{3}{*}{ Mean } \\
\hline & \multicolumn{4}{|c|}{ Makaronowa Warszawska } & \multicolumn{4}{|c|}{ Pyza } & \multicolumn{3}{|c|}{ mean } & \\
\hline & $1 \times 0.6$ & $1 \times 0.8$ & $1 \times 1$ & mean & $1 \times 0.6$ & $1 \times 0.8$ & $1 \times 1$ & mean & $1 \times 0.6$ & $1 \times 0.8$ & $1 \times 1$ & \\
\hline \multicolumn{13}{|c|}{2007} \\
\hline 5 May & 8.50 & 5.53 & 6.06 & 6.70 & 5.99 & 4.54 & 5.91 & 5.48 & 7.24 & 5.00 & 6.00 & 6.10 \\
\hline 15 May & 11.86 & 14.42 & 21.96 & 16.08 & 7.76 & 5.43 & 11.24 & 8.14 & 9.81 & 9.90 & 16.60 & 12.10 \\
\hline 25 May & 10.37 & 14.69 & 14.86 & 13.31 & 4.34 & 6.47 & 12.40 & 7.74 & 7.35 & 10.58 & 13.63 & 10.52 \\
\hline Mean & 10.24 & 11.55 & 14.29 & 12.03 & 6.03 & 5.48 & 9.85 & 7.12 & 8.14 & 8.52 & 12.07 & 9.57 \\
\hline \multicolumn{13}{|c|}{2008} \\
\hline 5 May & 6.46 & 7.78 & 5.66 & 6.63 & 10.47 & 19.24 & 15.00 & 14.90 & 8.46 & 13.50 & 10.30 & 10.80 \\
\hline 15 May & 10.75 & 9.19 & 7.78 & 9.24 & 14.35 & 15.47 & 12.59 & 14.14 & 12.55 & 12.30 & 10.20 & 11.70 \\
\hline 25 May & 9.89 & 14.72 & 12.45 & 12.35 & 4.95 & 3.96 & 8.91 & 5.94 & 7.42 & 9.34 & 10.68 & 9.14 \\
\hline Mean & 9.03 & 10.56 & 8.63 & 9.41 & 9.92 & 12.89 & 12.17 & 11.66 & 9.47 & 11.72 & 10.40 & 10.53 \\
\hline \multicolumn{13}{|c|}{2009} \\
\hline 5 May & 28.33 & 25.60 & 34.03 & 29.32 & 21.87 & 19.27 & 22.77 & 21.30 & 25.10 & 22.40 & 28.40 & 25.30 \\
\hline 15 May & 38.90 & 48.33 & 50.63 & 45.95 & 28.50 & 32.17 & 26.00 & 28.89 & 33.70 & 40.30 & 38.30 & 37.40 \\
\hline 25 May & 36.10 & 38.60 & 31.90 & 35.53 & 26.60 & 40.23 & 36.40 & 34.41 & 31.35 & 39.42 & 34.15 & 34.97 \\
\hline Mean & 34.44 & 37.51 & 38.85 & 36.94 & 25.66 & 30.56 & 28.39 & 28.20 & 30.05 & 34.03 & 33.62 & 32.57 \\
\hline \multicolumn{13}{|c|}{ mean } \\
\hline 5 May & 14.43 & 12.97 & 15.25 & 14.22 & 12.77 & 14.35 & 14.56 & 13.89 & 13.60 & 13.70 & 14.90 & 14.10 \\
\hline 15 May & 20.50 & 23.98 & 26.79 & 23.76 & 16.87 & 17.69 & 16.61 & 17.06 & 18.69 & 20.80 & 21.70 & 20.40 \\
\hline 25 May & 18.76 & 22.67 & 19.74 & 20.40 & 11.96 & 16.89 & 19.24 & 16.03 & 15.37 & 19.78 & 19.49 & 18.21 \\
\hline Mean & 17.90 & 19.87 & 20.59 & 19.46 & 13.87 & 16.31 & 16.80 & 15.66 & 15.89 & 18.09 & 18.70 & 17.56 \\
\hline
\end{tabular}


the highest average air temperature and the lowest amount of rainfall in September, the period of fruit ripening. The increase in the spacing between plants resulted in better sun exposure. The amount and intensity of light during the growing season have a significant effect on the content of total carotenoids in vegetables. Fruits exposed to maximum sunlight contain higher amounts of carotene than shaded fruits of the same plant (Kopsell and Kopsell 2006, Lester 2006), which was confirmed by the present study. The study did not show any significant effect of plant spacing on the content of L-ascorbic acid in fruits of spaghetti squash (Tab. 4). The content of L-ascorbic acid in fruits was higher for $1 \times 0.8$ $\mathrm{m}$ plant spacing only for plants sown on 5 May. Although light is not essential for the synthesis of L-ascorbic acid in plants, the amount and intensity of light during the growing season have a definite influence on the amount of L-ascorbic acid. L-ascorbic acid is synthesised from sugars supplied through photosynthesis in plants. In general, the lower light intensity during growth, the lower the L-ascorbic acid content in plant tissues (Lee and Kader 2000, Lester 2006).
The content of carotenoid compounds in spaghetti squash fruits depended on the cultivar (Tabs 2 and 3). Fruits of the 'Makaronowa Warszawska', with light orange flesh, contained more total carotenoids, on average, by $26.16 \mathrm{mg}$ $\mathrm{kg}^{-1}$ f.m. (30.4\%), and $\beta$-carotene by $3.80 \mathrm{mg}$ $\mathrm{kg}^{-1}$ f.m. (24.3\%) in comparison to the 'Pyza', with cream-coloured flesh. Squash cultivars with orange flesh are more valuable (Paris 1993, Murkowic et al. 2002), which was confirmed by the present study. Differences between cultivars in $\beta$-carotene content were greater for the sowing dates of 15 and 25 May than for the sowing date of 5 May. Only in 2008 (the year of the lowest mean air temperature and quite heavy rainfall in the second half of August and in September, during the fruit ripening period), with the sowing dates of 5 and 15 May, the content of $\beta$-carotene in the 'Pyza' fruits was higher than in the 'Makaronowa Warszawska' fruits. For the sowing date of 15 May, the largest differences in $\beta$-carotene content between cultivars were observed with $1 \times 1 \mathrm{~m}$ plant spacing, and with $1 \times 0.6 \mathrm{~m}$ plant spacing for the sowing date of 25 May. The L-ascorbic acid content in the fruits

Table 4. L-ascorbic acid content in spaghetti squash fruits depending on sowing date and plant spacing (mg kg-1 f.m.)

\begin{tabular}{|c|c|c|c|c|c|c|c|c|c|c|c|c|}
\hline \multirow{3}{*}{$\begin{array}{l}\text { Sowing } \\
\text { date }\end{array}$} & \multicolumn{11}{|c|}{ Cultivar and plant spacing $(\mathrm{m})$} & \multirow{3}{*}{ Mean } \\
\hline & \multicolumn{4}{|c|}{ Makaronowa Warszawska } & \multicolumn{4}{|c|}{ Pyza } & \multicolumn{3}{|c|}{ mean } & \\
\hline & $1 \times 0.6$ & $1 \times 0.8$ & $1 \times 1$ & mean & $1 \times 0.6$ & $1 \times 0.8$ & $1 \times 1$ & mean & $1 \times 0.6$ & $1 \times 0.8$ & $1 \times 1$ & \\
\hline \multicolumn{13}{|c|}{2007} \\
\hline 5 May & 63.00 & 70.67 & 66.00 & 66.56 & 67.00 & 63.33 & 63.67 & 64.67 & 65.00 & 67.00 & 64.80 & 65.60 \\
\hline 15 May & 55.67 & 57.67 & 66.67 & 60.00 & 64.67 & 72.67 & 67.67 & 68.33 & 60.17 & 65.20 & 67.20 & 64.20 \\
\hline 25 May & 66.00 & 67.33 & 69.33 & 67.56 & 68.33 & 65.33 & 69.33 & 67.78 & 67.17 & 66.33 & 69.50 & 67.67 \\
\hline Mean & 61.56 & 65.22 & 67.33 & 64.71 & 66.67 & 67.11 & 66.89 & 66.93 & 64.11 & 66.17 & 67.17 & 65.81 \\
\hline \multicolumn{13}{|c|}{2008} \\
\hline 5 May & 66.00 & 72.00 & 60.67 & 66.22 & 56.00 & 72.00 & 60.33 & 62.78 & 61.00 & 72.00 & 66.50 & 64.50 \\
\hline 15 May & 70.67 & 72.67 & 72.00 & 71.78 & 64.33 & 63.00 & 68.00 & 65.11 & 67.50 & 67.80 & 70.00 & 68.40 \\
\hline 25 May & 69.00 & 67.00 & 63.00 & 66.33 & 67.67 & 65.33 & 63.00 & 65.33 & 68.33 & 66.17 & 63.00 & 65.83 \\
\hline Mean & 45.56 & 70.56 & 65.22 & 68.11 & 62.67 & 66.78 & 63.78 & 64.41 & 65.61 & 68.67 & 64.50 & 66.26 \\
\hline \multicolumn{13}{|c|}{2009} \\
\hline 5 May & 52.67 & 55.00 & 55.33 & 54.33 & 55.33 & 53.67 & 50.33 & 53.11 & 54.00 & 54.30 & 52.80 & 53.70 \\
\hline 15 May & 56.33 & 50.00 & 53.33 & 53.22 & 50.33 & 51.33 & 57.00 & 52.89 & 53.33 & 50.70 & 55.20 & 53.10 \\
\hline 25 May & 55.33 & 53.67 & 52.67 & 53.89 & 56.33 & 51.00 & 55.00 & 54.11 & 55.83 & 52.33 & 53.83 & 54.00 \\
\hline Mean & 54.78 & 52.89 & 53.78 & 53.81 & 54.00 & 52.00 & 54.11 & 53.37 & 54.39 & 52.44 & 53.94 & 53.59 \\
\hline \multicolumn{13}{|c|}{ mean } \\
\hline 5 May & 60.56 & 65.89 & 60.67 & 62.37 & 59.44 & 63.00 & 58.11 & 60.81 & 60.00 & 64.40 & 59.40 & 61.30 \\
\hline 15 May & 60.89 & 60.11 & 64.00 & 61.67 & 59.78 & 62.33 & 64.22 & 62.11 & 60.33 & 61.20 & 64.10 & 61.90 \\
\hline 25 May & 63.44 & 62.67 & 61.67 & 62.59 & 64.11 & 60.56 & 62.44 & 62.37 & 63.78 & 61.61 & 62.06 & 62.50 \\
\hline Mean & 61.63 & 62.89 & 62.11 & 62.21 & 61.11 & 61.96 & 61.59 & 61.55 & 61.37 & 62.43 & 61.87 & 61.89 \\
\hline
\end{tabular}

$\operatorname{LSD}_{0.05}$ : years $=3.49$, sowing date $=$ n.s., plant spacing $=$ n.s., sowing date $\times$ plant spacing $=4.25$, cultivar $=$ n.s. 
of the examined cultivars of spaghetti squash did not significantly differ (Tab. 4). A study carried out in the area of Bydgoszcz found a higher content of carotenoids in 'Pyza' fruits immediately after harvesting, after six months of storage and in frozen fruits. The 'Makaronowa Warszawska' had a higher content of total carotenoids only in marinated fruits. 'Makaronowa Warszawska' fruits contained more vitamin $\mathrm{C}$ directly after harvesting in comparison to 'Pyza', but they showed higher losses of this vitamin during storage (Wojdyła et al. 2007). In the present study, the content of carotenoids in the fruits of the 'Makaronowa Warszawska' and 'Pyza' was higher and the content of L-ascorbic acid was lower than in the study carried out in the area of Wrocław and in Lithuania (Danilchenko 2002, Biesiada et al. 2006, 2008). The large differentiation in the content of carotenoids in spaghetti squash fruits was confirmed by studies carried out for other cultivars in Florida and Israel (Paris 1993, Beany et al. 1998, 2003).

\section{CONCLUSIONS}

1. Higher air temperature and lower amounts of precipitation during the spaghetti squash fruit ripening period favoured the accumulation of carotenoid compounds.

2. The content of total carotenoids and $\beta$-carotene in fruits was the highest for plants sown on 15 May. The sowing date did not affect the content of L-ascorbic acid in fruits.

3. The increase in plant spacing from $1 \times 0.6 \mathrm{~m}$ to $1 \times 1 \mathrm{~m}$ resulted in an increase in total carotenoid content, particularly for plants sown on 25 May. Plant spacing did not have a significant effect on the content of $\beta$-carotene and L-ascorbic acid in fruits.

4. The content of total carotenoids and $\beta$-carotene in fruits of the 'Makaronowa Warszawska' with light orange flesh was higher than in fruits of the 'Pyza' with cream-coloured flesh, while the content of L-ascorbic acid in fruits of both cultivars did not significantly differ.

\section{REFERENCES}

Beany A.H., Stoffella P.J., McCollum G., 2003. Production and post-harvest characteristics of spaghetti squash in South Florida. HortSci. 38(6): 1278.

Beany A.H., Stoffella P.J., Picha D., 1998. Production, fruit quality, nutritional value, and consumer preference of spaghetti squash. Proc. Fla. State Hort. Soc. 111: 221-223.

Biesiada A., Kucharska A., SokóŁ-Łętowska A., 2006. Plonowanie i wartość odżywcza wybranych odmian użytkowych Cucurbita pepo L. oraz Cucurbita maxima Duch. Folia Hort., Supl. 1: 66-69.

Biesiada A., Nawirska A., SokóŁ-ŁęTOWSKa A., KuChARSKA A., 2008. Yielding and biological value of some cultivars of Cucurbita pepo L. $1^{\text {st }}$ Symposium on Horticulture in Europe, 17-20 February, Vienna, Austria: 58-59.

BuczkowsKa H., SAwicki K., 2008. Zawartość wybranych składników w owocach papryki w zależności od odmiany i terminu sadzenia rozsady. Zesz. Probl. Post. Nauk Rol. 527: 73-79.

Cieślik E., 2009. Prozdrowotne właściwości warzyw. Zesz. Probl. Post. Nauk Roln. 539: 87-97.

DAnilchenKo H., 2002. Effect of growing method on the quality of pumpkins and pumpkin products. Folia Hort. 14(2): 103-112.

JANECZKO Z., 2003. Owoce i warzywa jako źródło prozdrowotnych substancji o właściwościach antyoksydacyjnych. Folia Hort., Supl. 1: 23-25.

Kopsell D.A., Kopsell D.E., 2006. Accumulation and bioavailability of dietary carotenoids in vegetable crops. Trends Plant Sci. 11(10): 499-507.

KrZesiński W., Knaflewski M., 2002. The effect of solar radiation on beta-carotene and other carotenoid content in carrot roots. Folia Hort. 14(2): 25-33.

LeE S.K., KAdER A.A., 2000. Pre-harvest and post-harvest factors influencing vitamin $\mathrm{C}$ content of horticultural crops. Postharvest Biol. Technol. 20: 207-220.

LESTER G.E., 2006. Environmental regulation of human health nutrients (ascorbic acid, $\beta$-carotene, and folic acid) in fruits and vegetables. HortSci. 41(1): 59-64.

LipeCKi J., LibiK A., 2003. Niektóre składniki warzyw i owoców o wysokiej wartości biologicznej. Folia Hort., Supl. 1: 16-22.

Murkovic M., Mülleder U., Neunteufl H., 2002. Carotenoid content in different varieties of pumpkin. J. Food Comp. Anal. 15: 633-638.

NAIDU K.A., 2003. Vitamin C in human health and disease is still a mystery? An overview. Nutr. J. 2: 7.

PARIS H.S., 1993. Orangetti squash in field, market, and kitchen. HortTechn. 3(1): 95-97.

Perkins-Veazie P., 2010. Cucurbits, watermelon, and benefits to human health. Acta Hort. 871: 25-32.

PN-90/A-75101.11, 1990. Przetwory owocowe i warzywne. Przygotowanie próbek i metody badań fizykochemicznych. Oznaczanie zawartości witaminy $\mathrm{C}$.

PN-90/A-75101.12, 1990. Przetwory owocowe i warzywne. Przygotowanie próbek i metody badań fizykochemicznych. Oznaczanie zawartości karotenoidów i $\beta$-karotenu.

Wadas W., Kalinowski K., 2010. The effect of selected agricultural factors on the yielding of spaghetti 
squash (Cucurbita pepo L.). Acta Sci. Pol., Hortorum Cultus 9(2): 93-101.

WojdyŁa T., Wichrowska D., Rolbiecki R., Rolbiecki S., Weltrowska-MedzińsKa B., 2007. Zawartość wybranych składników chemicznych w dyni makaronowej świeżej po zbiorach i po przechowywaniu oraz konserwowanej - w zależności od nawadniania i odmiany. Żywność 52: 82-89.

Wolbang C.A., Singh D.P., Sykes S.R., McInerney J.K., Bird A.R., Treeby M.T., 2010. Influence of pre- and postharvest factors on $\beta$-carotene content, its in vitro bioaccessbility, and antioxidant capacity in melons. J. Agric. Food Chem. 58(3): 1732-1740.

WPEYW WYBRANYCH CZYNNIKÓW AGROTECHNICZNYCH NA ZAWARTOŚĆ ZWIAॄZKÓW PROZDROWOTNYCH W DYNI MAKARONOWEJ (CUCURBITA PEPO L. SUBSP. PEPO)

Streszczenie: Badano wpływ terminu siewu $(5,15$ i 25 maja $)$ i rozstawy roślin $(1 \times 0,6 \mathrm{~m}$, $1 \times 0,8 \mathrm{~m}$ i $1 \times 1 \mathrm{~m}$ ) na zawartość karotenoidów oraz kwasu L-askorbinowego w owocach dwóch odmian dyni makaronowej ('Makaronowa Warszawska' i 'Pyza'). Doświadczenie polowe przeprowadzono w środkowo-wschodniej Polsce. Owoce dyni makaronowej zbierano w fazie pełnej dojrzałości, od początku września do początku października. Zawartość karotenoidów ogółem i $\beta$-karotenu była największa przy siewie 15 maja. Termin siewu nie miał wpływu za zawartość kwasu L-askorbinowego. Zwiększenie odległości między roślinami z $1 \times 0,6 \mathrm{~m}$ do $1 \times 1 \mathrm{~m}$ powodowało zwiększenie zawartości karotenoidów ogółem, szczególnie przy siewie dyni makaronowej 25 maja. Rozstawa roślin nie miała istotnego wpływu na zawartość $\beta$-karotenu i kwasu L-askorbinowego. Owoce odmiany 'Makaronowa Warszawska' o jasnopomarańczowym miąższu zawierały więcej karotenoidów ogółem i $\beta$-karotenu niż owoce odmiany 'Pyza' o kremowym miąższu. Zawartość kwasu L-askorbinowego u obu odmian nie różniła się istotnie.

Received September 8, 2011; accepted March 28, 2012 